\title{
The Loss of Public Sphere: Outdoor Advertising and Commercialization of Public Spaces in Sleman, Yogyakarta, Indonesia
}

\author{
PUJI RIANTO \\ Universitas Islam Indonesia, Indonesia
}

\begin{abstract}
The commercialization of public spaces is one of the crucial issues in Yogyakarta Special Province, Indonesia. This study examines the loss of public spaces on Kaliurang and Affandi street, Sleman, Yogyakarta. Applying the case study as a research method, the data were collected through close observations to the advertisements, billboards, banners, posters, and other outdoor media along Jl. Kaliurang and Affandi street. During the data collection, the author has taken some photos in certain spots of these two locations. The study finds that the massive occupation of outdoor advertising in the public spaces along these two areas has not only causing visual trash but also causing the loss of the public sphere. It is caused by several factors. One of the most important factors is the weakness of local government regulations. Another factor is the spatial capitalization of the Yogyakarta Special Region and Sleman Regency in recent years as could be seen from the wide establishment of hotels, malls, supermarkets, and minimarkets in Yogyakarta. As a result, the public does not have enough space to express their voices and interests. Furthermore, the dominance of outdoor advertising has resulted in the dominance of commercial discourse in public spaces and has simultaneously marginalized or even eliminated public discourse. Public space has eventually transformed into commercial and has no longer become an important tool for democracy. Conversely, it has become an important tool for promoting consumer culture.
\end{abstract}

Keywords: Commercialization, public space, public sphere, outdoor advertising, commercial discourse.

\section{INTRODUCTION}

Public space, as Miller has pointed out, is not merely a static physical space, but rather a hybrid of physical space and the public sphere (Gehl \& Matan, 2009, p. 107). In such a case, public space refers to the constellation of ideas, actions, and environments. Therefore, public space, which is closely related to the public sphere will always be a battle of various groups' interests, especially in a city with a high level of plurality. Each group competes for territory and discourse to achieve certain power and hegemony (Gaffikin et al., 2010).

The focus of this study is the commercialization of public spaces on Affandi and Kaliurang streets in Sleman Regency, one of the districts in the Special Province of Yogyakarta, Indonesia. Public spaces on both roads have been decided as the focus of the study since they have transformed in such a way into commercial areas. Along these roads, almost all of the buildings have become commercial places, such as coffee shops, supermarkets or minimarkets, working spaces, and culinary areas. This transformation was also followed by the high number of visitors along the road, and it continues to increase from year to year. It has provided excellent spaces for outdoor advertisings. Therefore, not surprisingly, on both roads, we may easily find many large-sized outdoor advertisings crossing the roads. In fact, we may say that outdoor advertisings on Affandi and Kaliurang streets have become the most crowded within Sleman Regency. 
Outdoor advertising in Yogyakarta has attracted many studies by scientists with social and artistic or architectural backgrounds. A scholar with an urban planner's background usually focuses on the use of public spaces, such as pedestrian areas for local communities and their roles in improving public life (Nasution \& Zahrah, 2016). In this study, public spaces are interpreted as a physical space in urban planning to improve the quality of life of its inhabitants. Therefore, public space is claimed to be successful if it provides a conducive space for social interaction, attracts visitors to carry out various activities, supports recreational and informal activities (Nasution \& Zahrah, 2016, p. 66). Other studies have focused on community participation in planning and building public spaces (Ismail \& Said, 2014). In this case, public participation is important to safeguard the acts of vandalism that can damage the public function and the aesthetics of public space. The understanding of public space as a physical space and its contribution to the quality of life of urban communities has implications for the access and rights of vulnerable groups. Such studies were developed by Esfandfard, Amat, and Wahab (2017) in their studies on ValiAsr Street, the main road and commercial centre in Tehran. Poor quality of paving and uneven surfaces makes difficult access to vulnerable groups such as wheelchair users and visually impaired people.

Wicaksono, Susilo, and Lestari (2008), who have also examined the massive outdoor advertising on Affandi street, argued that the strong commercial interests have made the public interest marginalized. Overlapping advertisements on Affandi street have also created 'visual trash'. According to their survey about public perceptions on outdoor advertising along the street, some respondents perceived that there was no problem with the outdoor advertising, while other people stated that the government should pay more attention to the aesthetics and users' safety. Another study has questioned the aesthetic aspects of outdoor advertisings (Harsanto, 2014). Harsanto has shown that placing outdoor advertisements irregularly has not only created visual pollutions@ but also devastated the aesthetics of the city, which in turn would influence the public perceptions about Yogyakarta and Sleman. However, the implications of this spatial commercialization to the public sphere have not yet been studied. In fact, the domination of commercial discourse has far more serious implications in public life. According to Philips and Jorgensen (2007), discourse is an important part of social life, while social changes occur in and through discourse. In this sense, public attention to the public space, which is a physical space that creates social ties (Aubin, 2014, p. 90), is fundamentally important, but the attention should go further to the extent to which physical space is able to build public discourse or not.

This study was conducted to answer two main problems, i.e. how the hypercommercialization has caused the loss of public spaces along Affandi and Kaliurang roads, and how to further implications of such hyper-commercialization to the public sphere. By answering these questions, this study expects to provide a valuable contribution to the academic discussions as well as practical solutions to the loss of public spaces in the Sleman Regency especially, and in Indonesia generally.

\section{LITERATURE REVIEW}

Public space has vital roles in democracy since it is closely related to the public sphere (Crawford, 1995; Parkinson, 2013). The public sphere is defined as a 'space of democracy' in which every citizen has the same rights to inhabit and public discourse takes place (Crawford, 1995, p. 4). The public sphere also promotes public debate openly, mobilizes public concern and participation (Voronkova \& Pachenkov, 2011, p. 198; Németh, 2012). 
Social and urban planning scholars have investigated the meaning and role of public space in the lives of modern society. However, it is not easy to provide a satisfactory definition of what is public space. For example, public space is usually defined based on ownership (Parkinson, 2012). However, such definitions often make difficulties in analysis, for example, a place owned by the public (state) cannot always be easily accessed by the public itself. Military facilities or health laboratories are owned by the government but are very restricted to the public. Conversely, private-owned places such as malls, coffee shops, or plazas can be easily accessed by the public.

Differences between public and private are rooted in the tradition of political theory and liberal democracy (Parkinson, 2012; Parkinson, 2013). The distinctions are related to ownership, control, and access. Public space means that space is owned by the public, open access, and no control over it. Instead, a space becomes private if people cannot use or access it without permission. Violation of private space means a violation of personal rights and ownership law. People can, therefore, be prosecuted for committing these violations.

Publicness is a keyword in understanding public space. Varna and Tisdel have categorized previous studies that try to understand publicness into two categories, i.e. inductive/external and deductive/internal (Németh, 2012, p. 3). The inductive approach seeks to conceptualize publicness through understanding "what's out there", outside of people. Madanipour has identified that previous studies in this approach rely on ownership regimes, seek to understand publicness in the framework of access, agency, and interest (Németh, 2012, p. 3). Access means the ability of people to occupy or use public space, while the agency is the locus by which control and decision making are situated. Interest concerns the benefits caused by the use of the space. In public space, profits will be shared for the public, while private property belongs to individuals or private. Kohn has defined publicness with regard to the three core criteria, i.e. ownership, accessibility, and inter-subjectivity (Németh, 2012, p. $3)$. Thus, the inductive/external approach basically understands public space as a physical sense.

In contrast to the inductive approach, which focuses on ownership, access, and control, the deductive/external approach focuses more on the socially constructed meaning of the public space. This approach seeks to understand public space from the beholder's perspective (Németh, 2012, p. 4). Iveson has suggested three possible ways by which space might be 'made public', i.e. space has become a place for public addresses, as an object of the public debate itself, or as a means to understand 'who belong' in any definition of the public (Németh, 2012, p. 3-4).

Contemporary literature on public space in urban societies has understood public spaces as a framework of two models. The first model approaches public space as a public display of distinct differences and a closed identity is affirmed. The second model describes public space as a relational space where greater pluralism of identities is negotiated and contested continuously (Gaffikin et al., 2010, p. 496).

In contemporary discourse, openness and participation as main characteristics of public space are threatened by two power, namely the state and the market (Németh, 2012). The market threatens public spaces in two forms, i.e. privatization and commercialization. When privatization happened, public space is no longer 'public' in terms of open access to all people. Privatization means that 'public property' has turned into the private property so that there are restrictions on public access. Commercialization is also a threat to the public space because it shifts government attention from the public needs to commercial interests. For the 
sake of gaining income, the government usually tends to make public spaces for commercial interests. Visual trash that damages the aesthetics of the city was caused by the government as they have more prioritized taxes over the public interests. In many cases, privatization and commercialization occur simultaneously. When the public is commercialized, it simultaneously changes to the private. Referring to Arendt, Hardiman (2010, p. 193) argued that the growth of capitalism and the crisis of the public sphere took place reciprocally. The expansion of the market into public, which is characterized by freedom and autonomy was replaced by market mechanisms in the form of survival for the consumption and conquest of others. As a result, public space is lost in the dominance of markets that are voluntarily accepted by individuals. Gramsci referred to this phase as 'hegemony' (Hardiman, 2010, p. 193).

The state can also be a threat to public space (Imam, 2010; Németh, 2012). For the reasons of public order, the state can secure public spaces by limiting citizens' access. As a result, people cannot use public spaces to express their opinions, protests, also political participation. When the state intervened too far in the public spaces then the 'public sphere' is no longer functioning for democracy. Physically, the public space still exists, but its function for democracy has suffered.

Parkinson (2013, p. 687), after differentiating between public and private, argued that public space has at least three meanings, i.e. openly accessible space; and/or space of common concern (in terms of using common resources or having common effects); and/or space used for the performance of public roles. Therefore, public space has vital roles in strengthening democracy, i.e. being a public sphere, in the sense if public space is able to perform the following roles (Parkinson, 2013, p. 688; Parkinson, 2012, p. 36):

1. Articulating interests, opinions, and experiences;

2. Making public claims, i.e. defining collective problems or defending existing arrangements, requesting action or inaction on collective problems, expressing, setting, and defending norms, and making claims on public resources;

3. Deciding what to do, or what not to do, to address public claims, including weighing up options;

4. Scrutinizing and giving account for public action and inaction.

When public space succeeds in performing its roles as demonstrated by Parkinson, then public space has function itself as a public sphere. In this notion, public space is understood as a condition for the implementation of the public sphere. As a condition, public space will never remain; on the contrary, it will continue to change (Voronkova \& Pachenkov, 2011; Carmona, 2015).

\section{METHODOLOGY}

This study focuses on the commercialization of public spaces in Affandi and Kaliurang streets, Sleman Regency. As many studies have shown that public space is dynamics, determined by a variety of very complex factors (Carmona, 2015). Therefore, the understanding of the shifts and changes of public spaces in a region should also take into account the factors associated with these changes, including the political, economic and socio-cultural context.

Taking this complexity into account, I used a case study as a suitable method to answer the research problems. As Robert K. Yin (2006) has pointed out, a case study is the most appropriate method for answering the question of 'how' and 'why' when the researcher has 
no control over the object or subject of study. In addition, the use of a case study provides benefits since it allows the researcher to use a variety of evidence sources. Here, the selected case is not due to the uniqueness of the case itself, but to understand other issues. Therefore, the design is not an intrinsic case study, but instrumental (Stake, 2009; Creswell, 2015). Here, case studies are conducted to understand specific issues, problems, or concerns (Cresswell, 2015 , p. 137; Stake, 2009, p. 301). Thus, the main interest is in the issue or problem, and not in the case itself. The case is only as a support for understanding the problems or issues discussed in the study (Stake, 2009, p. 301).

The data were collected through observations along the Kaliurang and Affandi streets. I have conducted several observations on both roads, focusing on three things. First, I have observed the types of outdoor advertising in detail and the sizes of each advertising on both roads. The differences will mainly be analysed between commercial and non-commercial advertisements. Second, I have observed the placement of outdoor advertisements, how they are placed, both on the left and right sides of the road, or on the open spaces above the two roads. Third, I have focused on the aesthetic values and density of the advertisements. During the observations, I have also taken a number of photos of the advertisements. As a case study (Yin, 2006), data were also collected from other sources, such as legal documents, research reports, online and print media news, and others. The data were analysed based on theoretical propositions, which is a common strategy carried out in the case study analysis (Yin, 2006, p. 136-137). In this model, theoretical propositions will be the basis for prioritizing and developing the main relevant themes for analysis.

\section{RESULT AND DISCUSSION}

\section{The Political Economy of Public Space Commercialization in Sleman}

The commercialization of public spaces in Sleman, especially along Affandi and Kaliurang streets, are remarkably inseparable from the broader context of commercialization in the Special Region of Yogyakarta. The commercialization of Yogyakarta is not only indicated by the occupation of outdoor advertisings on public spaces but also by the uncontrolled construction of hotels, malls, supermarkets or mini markets in this region. This commercialization has been criticized by a local artist, the Jogja Hip Hop Foundation, in their song entitled 'Jogja Ora Didol' (Yogyakarta is not for sale). This song is a reflection and at the same time is a critical call for the development of the Special Region of Yogyakarta, which is more concerned with the commercial sides and simultaneously not concerned with public needs.

In many cases, the construction of hotels and malls were not accompanied by adequate parking facilities. Consequently, they used the sidewalk provided for pedestrians as the parking areas. In fact, the sidewalk for pedestrians is not only for walking but also for other activities. As stated by Mateo-Babiano (2012, p. 456), "Extending the idea that streets is not only for distribution but also for communication". Mateo-Babiano's study in Bangkok has shown that important activities of pedestrians are carried out 2-3 times a day, such as travelling for meals or carrying out other tasks. Therefore, when sidewalks are disturbed by outdoor advertisings, the convenience of pedestrians is also disrupted.

Commercialization is also accompanied by the growth of uncontrolled outdoor advertisings, creating visual trash, and pollution. Outdoor advertisements are not well organized and chaotic. This concern was voiced by the Hip Hop Foundation, which is reflected in the following verse. 


\section{"Merapi was furious, his physical figure was gone \\ Advertise closure, making it difficult to see \\ On the road, billboards transverse \\ Visual waste must be thrown away"}

The commercialization of public spaces in Sleman is also related to the development of Yogyakarta as an agglomeration town. This growth has significant impacts on housing areas, hotels, and modern markets (Setiawan, Haryono \& Burhan, 2014, p. 241). It has been followed by land-use changes in the agricultural areas in Sleman and Bantul, two districts in Yogyakarta. The growth of hotels was the result of tourism policies launched by the government since the 1980s. Various attributions of Yogyakarta as a city of tourism and education have attracted most of the urbanization into this region for a variety of purposes. This has created a crowded environment in Yogyakarta in several areas, such as Kaliurang and Affandi streets, as well as new challenges for urban planning. For the capitalist, a densely populated environment means a market for the industry, and it is well recognized by the producers. Therefore, they occupied public spaces on both roads through establishing shopping areas, and discursively through installing outdoor advertisings.

A recent study found that outdoor advertising turned out to be far more effective than electronic advertising. Public exposure to outdoor advertising is only slightly compared to television (Ratnasari, 2016). The enormous penetration has caused the outdoor media to become one of the favourite promotional facilities, especially in high-traffic roads. It is perhaps the background of the intense outdoor advertising surrounding Affandi and Kaliurang streets, as they are considered effective in influencing potential customers. For people who go through the street almost every day, exposure to outdoor advertisings will be far more massive than television. When we pass the road then we cannot refuse to see outdoor advertising. This is different from television, which we can turn off or change the channel when we do not want to watch certain shows.

From a global perspective, the establishment of malls, supermarkets, minimarkets, and hotels in Yogyakarta are the extension of the neoliberal victory in the 1980s, whose echoes in Indonesia continue up until now. A neoliberal order is a way of restructuring the social class (Harvey, 2009) and the dominance of the market (homo economics) into other human dimensions (Herry-Priyono, 2004). In the neoliberal order, the market is considered the best mechanism in organizing human life. The study of Carmona (2015) has shown that the narrative of public space cannot be separated from the relation of the political economy of the policies that form it. As shown in the case of the City of London, the neoliberal path, which was closely held by Margaret Thatcher, has influenced the physical spaces and the development processes that have been done and still will be. Carmona (2015, p. 377) further stated that "The process of urban design will evolve over time, reflecting changes in society, the economy, and the prevailing politics, and overlaying the historically defined processes of place with a characteristic contemporary polity".

From a political economy point of view, the expansion of outdoor advertising in Kaliurang and Affandi streets cannot be separated from the desire of the regional government to generate regional income from the advertisement tax. Regent Regulation (Peraturan Bupati) of Sleman No. 53/2015 which was updated with No. 13.1/2018, has only provided a basis for controlling advertisements, especially of those are unlicensed and disrupt aesthetics. However, this regulation did not include any ad-free area or at least 
restrictions on outdoor advertising in an area. The regulation itself, which is based on Law No. 26/2007 concerning Spatial Planning, did not give any attention to public space at all. The law only defined space as "a place that includes land space, sea space, and air space, including space within the earth as a unitary area, where humans and other creatures live, carry out activities, and maintain their survival". This definition only concerns the physical dimension of public space and is limited to the health and welfare issues of the community (Nasution, Salleh, \& Wahid, 2014). In fact, public spaces and their existence in preparing or acting as a public sphere are indeed important. The public sphere requires discourse, and it becomes a prerequisite for the creation of a democratic space.

\section{The Transformation from Public into Commercial Space}

The dominance of outdoor advertisings on Affandi and Kaliurang roads directly shows the transformation of public space into commercial. The public space in this study is not only understood as a road that can be accessed by anyone, but also as open space above it and along the edges. 5 When the two roads are dominated by commercial advertising, also a little political advertising, then the public space has turned into commercial. The public no longer has access to represent themselves in the open space except as connoisseurs of all information and commercial persuasion.

Almost all spaces along Affandi and Kaliurang roads have been filled with outdoor advertising, and almost completely leave no space (Figure 1 and 2). Outdoor advertisements overlap to get public attention. Aesthetically, the placement of such outdoor advertisements has created visual trash and pollution. Besides, outdoor advertising was placed along the sidewalk provided for pedestrians and has taken pedestrian rights. Although the regulations in Sleman have explained that each signboard of the store should be categorized as an advertisement and must be reported, most of the store owners did not ignore it at all (Wicaksono, Susilo, \& Lestari, 2008). Many stores do not report to the government for the signboard that they installed.

This situation is exacerbated by the public spaces that are claimed by the private. There is a sense of belonging to the public spaces by individuals. For example, because the sidewalk is located in front of his shop, then it is his right to put up bulletin boards or advertisements. Ironically, this also happens for public roads. The scarcity of parking lots has made shop owners claimed that the public roads in front of their shops are only for parking areas of their customers (Purbadi, 2012). They ignore that the road is a public space where citizens are guaranteed the right to use. Such neglect occurs widely because of the low level of knowledge and awareness about public and private spaces. The liberal democratic tradition in which the concepts of public and private are well defined is not deeply rooted in Indonesia. 


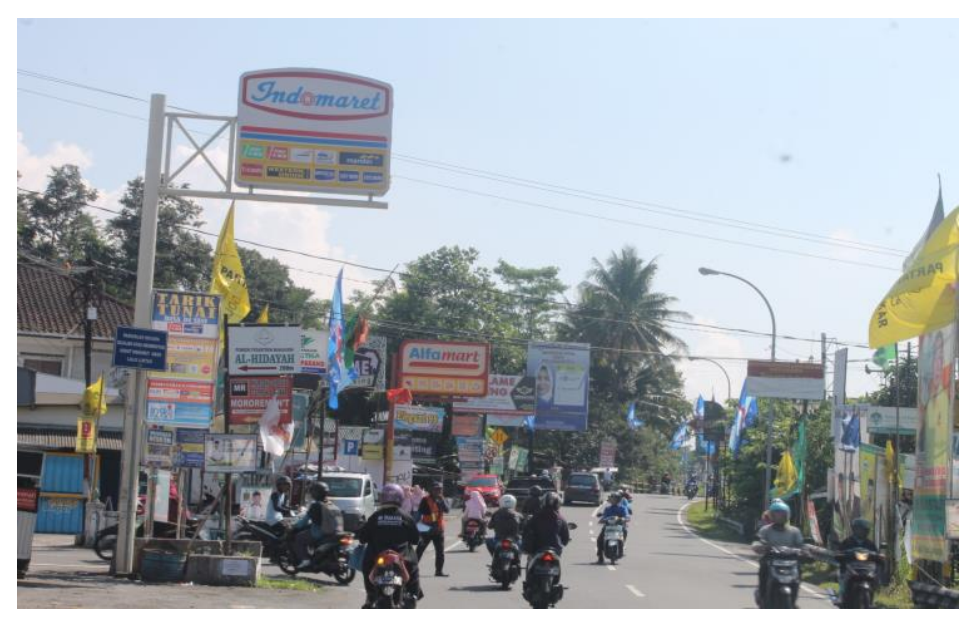

Figure 1: Outdoor advertisings on Kaliurang road show overlapping and leaving visual trash.

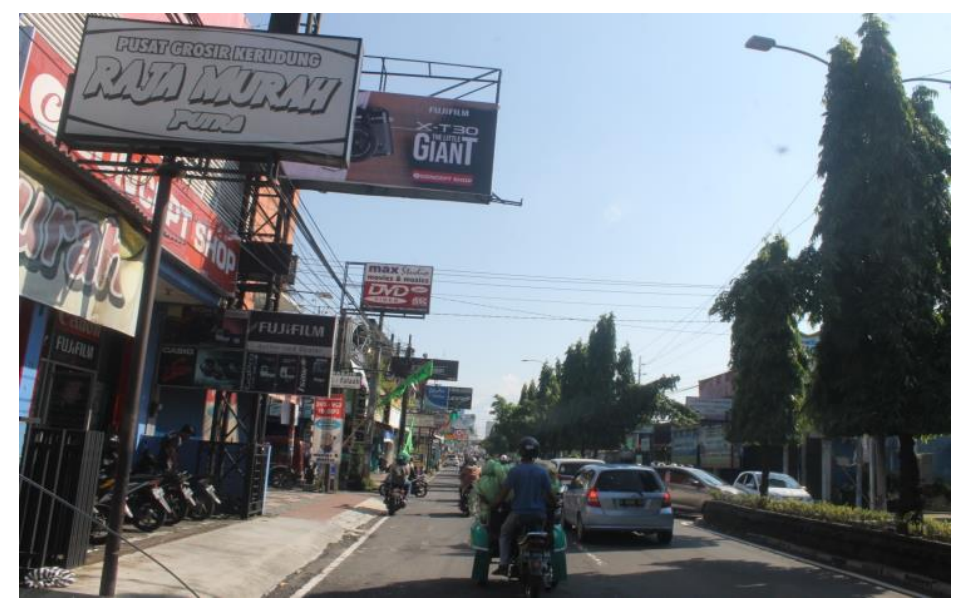

Figure 2: Outdoor advertisings on Affandi street take pedestrian rights.

The dominance of outdoor advertising along Affandi and Kaliurang roads has made the public interests marginalized. As shown in Figure 3, on the Kaliurang road, Ngaglik District Office, which is located in this road often delivers announcements and information, but the placement of the information board is hidden, which is very different from the commercial advertisings that are clear and easily read. The call for birth control in the form of a family planning program, for example, is not installed in the direction of the people who go through the road. Meanwhile, other noticeboards, such as the community study hours, are left dull and neglected (Figure 3). The only striking public advertisement is the dissemination of cancer warning held by the Healthy Community Movement (Gerakan Masyarakat Sehat - Germas). However, under the advertisement, the Library Integrated Service Unit announcement board was made very small and marginalized within large commercial advertisements (Figure 4). The existence of funds seems to be the reason whether the bulletin boards are striking or not. 


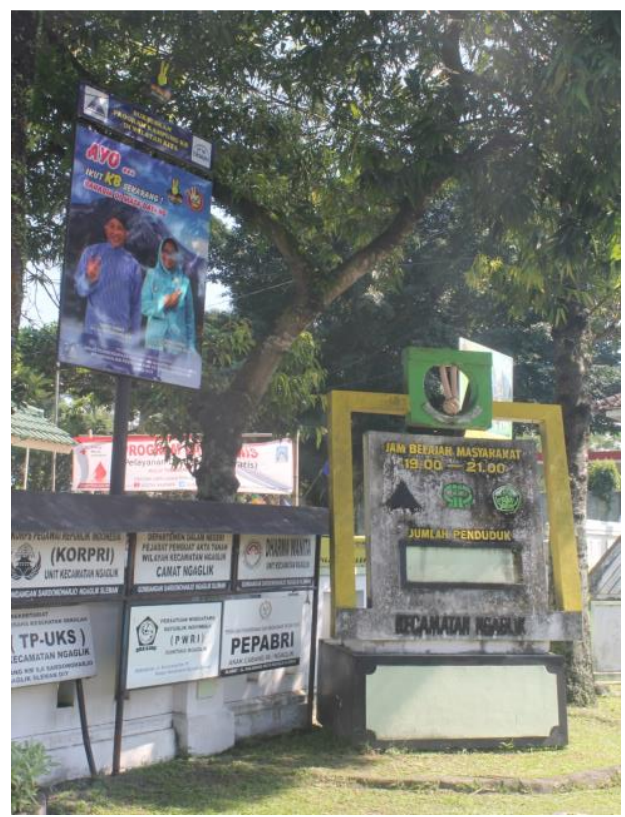

Figure 3: Announcement and advertising board at government office.

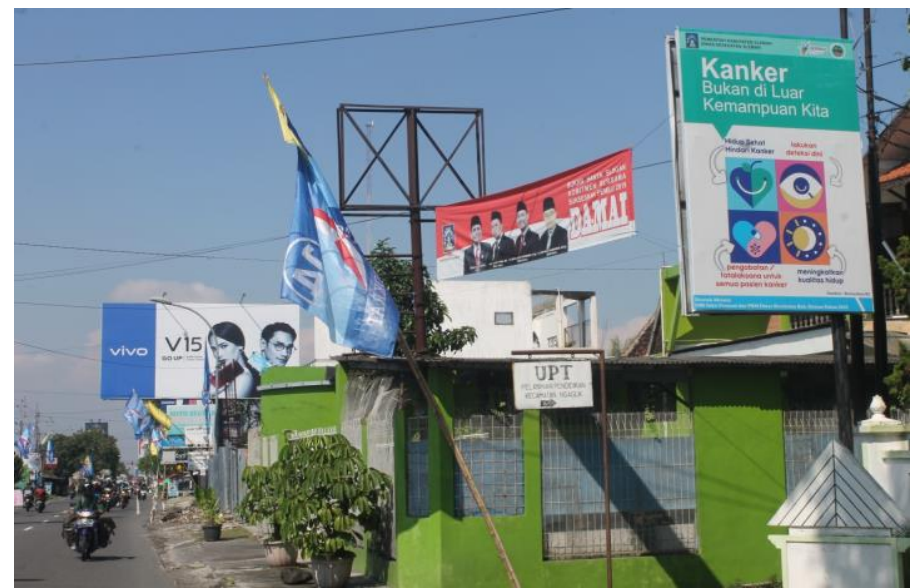

Figure 4: Official board among commercial and political advertisements.

Thus, it is clear that the two roads have been filled with outdoor advertisings that occupy a large part of public spaces. As a result, public space is almost completely lost and replaced by commercial places, which means that the discourse is ultimately dominated by the commercial.

\section{Further Implications}

As a commercial means, outdoor advertising introduces products and builds interest in those products, targeting people as consumers, not a citizen. Outdoor advertising will constantly increase the consumer's desire. This trend has been shown by Voronkova and Pachenkov (2011) in the context of European cities. Broadly speaking, greater attention to private interests rather than to social issues can threaten civil liberties and diversity (Nemeth, 2012, p. 1). When public space turns into commercial, there will appear further problems. First, public space fails to transform itself into the public sphere. Public space, in the physical sense, is a condition that allows the emergence of the public sphere. However, not all public spaces 
The Loss of Public Sphere: Outdoor Advertising and Commercialization of Public Spaces in Sleman, Yogyakarta, Indonesia

Puji Rianto

eventually transformed into public spheres. This requires active citizens to engage with public problems. At a minimum, they have attention to public problems and discuss them before making movements. The opportunity of this transformation, from public space into the public sphere, will be completely closed when the public space has been transformed into commercial space.

Second, representation. Public space should be open to anyone, especially community and subaltern groups. These groups should be able to represent themselves, present in the public space as part of the community. Transformation of public space into commercial areas, along Affandi and Kaliurang roads, instead of giving space to subalterns, a community, in general, are not well represented.

The third is the dominance of commercial discourse. Based on discourse theory, outdoor advertising is text with commercial discourse. The direct impact of this commercial discourse is a consumptive culture. The process can be described as such: outdoor advertising builds a continuous commercial discourse. Then, the discourse in a certain period of time will build awareness in the community, which will slowly be internalized and not realized. When internalization occurred, the discourse has succeeded in establishing a commercial culture or consumption. It can be said that the hegemony of the commercial discourse along the Kaliurang and Affandi roads will create a new habitus, a concept introduced by Bourdieu as a pattern that is permeated and becomes a habit (Haryatmoko, 2016). When people cross that street, then two things immediately come in the mind, shopping or just passing on that street. Whether shopping or simply passing will not be separated from commercial actions or discourses. Someone who just passes along the road will face commercial discourse continuously, and this will build certain awareness, precisely commercial awareness. This will encourage a further hegemony, such as awareness of space. When Affandi and Kaliurang roads are co-opted by commercial discourse, then peoples' construction of the two roads will also change accordingly. The social construction on both roads is becoming clear and stable, as a commercial area. At this level, spatial awareness is at the hegemonic status. In the end, the situation has changed the individual identities of citizens into mere consumers. In relation with, Sastrapratedja (2010, p. 275) has argued, "Public space shrinks, when citizens emphasize their identity as consumers rather than as citizens who participate in public spaces".

To save the loss of public space, there are at least two routes that can be used to build an ideal 'public space' for democracy (Herry-Priyono, 2010, p. 386-394). The first one is the route of public policy. It must be stressed that the government is no longer considered as the sole agent in the public policy processes, the government is not the only driver of the public policy. But, there are some powers in society that can also drive public policies. The revitalization of government agencies is important so that they always become 'the guardian' of public spaces. Second, education. In the current national education conditions, the market orientations are far more popular than public purposes. Therefore, education should be carried out to encourage public values for all existing entities. The government and the private education sectors should always orientate at public services. It will involve a continuous battle of discourse and policy. Another path is the agency re-education which is carried out on concrete actors that become pillars of public spaces, such as television managers, urban planning consultants, or school education providers. 


\section{Public Resistance}

Commercialization of public space in the form of outdoor advertising that disrupts aesthetics and social comfort has encouraged citizen resistance. The Jogja Hip Hop Foundation (JHF) has mainly emerged for countering commercialization in Yogyakarta. Thus, there was a strong relationship between the appearance of the work of art (JHP) and the social conditions of the community. When the social conditions of society are disadvantaged due to commercialization, works of art appear as a form of resistance (Usada, 2015).

Meanwhile, outdoor advertising, which is considered to have disrupted the aesthetics of Yogyakarta and Sleman Districts, has also given rise to the community resistance in the form of a social movement, namely Reresik Sampah Visual (Visual Waste Cleaning Community). It was initiated by Sumbo Tinarbuko, a lecturer at ISI Yogyakarta. This group actively educates and invites the public to take care and even if necessary to intervene in cleaning up the visual waste. Primarily, they clean up outdoor advertisings that violate rules, such as located at sidewalks and cultural heritage buildings. As early 2019, this group has issued an online petition through change.org to call for keeping public spaces from privatization (Figure 5).

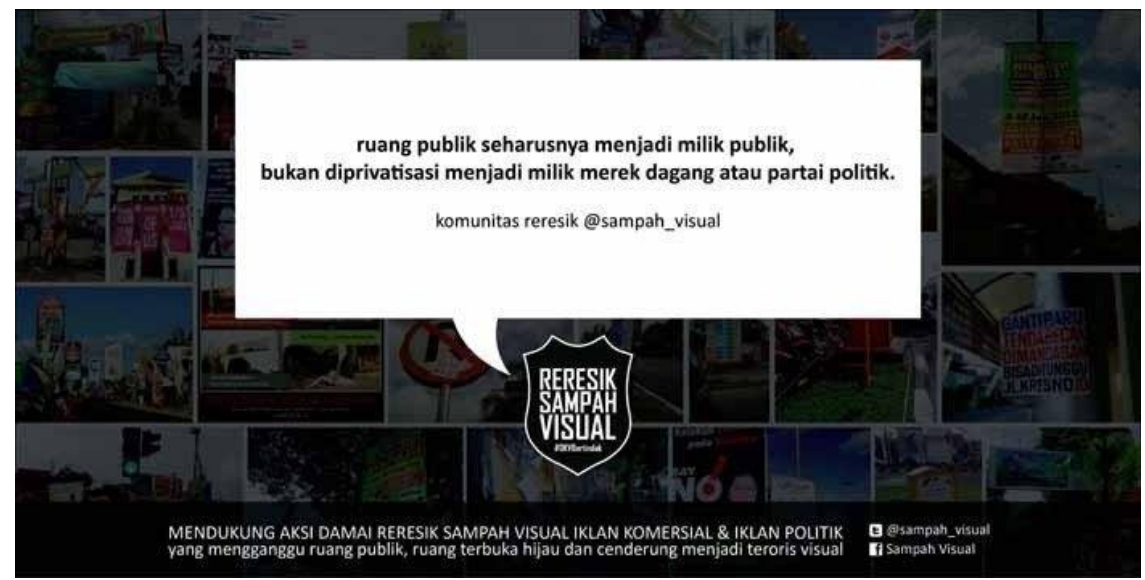

Figure 5: Online petition carried out by Komunitas Reresik Sampah Visual (Visual Waste Cleaning Community) through Change.org at the beginning of 2019.

\section{CONCLUSION}

This study concludes that the loss of public spaces on Affandi and Kaliurang roads occurred due to strong commercialization. It has marginalized the public sphere. As a result, public spaces in both areas have no longer important meanings of democracy. In contrast, public space has turned into commercial. There are two factors that may cause this condition, namely the weakness of local policies and commercialization of the Yogyakarta region in a broader context. Local regulations in Sleman District have only specified certain regions that are allowed to place outdoor advertisements. Public space itself has never been defined in these local regulations. Moreover, the enforcement of these regulations is often inconsistent. Meanwhile, the commercialization of public space continues, as the Yogyakarta region is becoming a thriving and dense city. Commercialization is always related to financial issues, as well as efforts to get taxes from outdoor advertising.

The fail of functioning as a public sphere has important consequences. Public space will not be able to give space for the voice and representation of subaltern and minority groups. Fundamentally, in the discursive level, the domination of commercial advertisements 
would generate the social construction of the place as a commercial area. The public would perceive the two roads as merely commercial areas, and they will perceive themselves as mere consumers. This kind of awareness is becoming a hegemonic status.

The focus of this study was only two roads in Sleman Regency, but other roads and regions are dealing with a similar problem. Therefore, further studies should be developed using critical approaches in order to encourage public emancipation. Local governments must seriously take care of maintaining public spaces so that they are not lost by outdoor advertisings that grow out of control. The tax on commercial advertising is important for development, but it is not more important than maintaining democratic spaces. Thus, public rights must be protected from the excessive intervention of commercial power. The public must also be more active in fighting for public spaces that can be used to build public discourse and representations of diverse groups and identities.

\section{ACKNOWLEDGEMENT}

This research was conducted independently without financial sponsorship from any parties. The researcher has no conflict of interest over the research conducted. The author would like to thank Intania Poerwaningtias, a researcher at Pemantau Regulasi dan Regulator Media (PR2Media), for plenty of time to read the initial draft of this article.

\section{BIODATA}

Puji Rianto is a lecturer at the Department of Communication, Universitas Islam Indonesia, Yogyakarta, Indonesia. His research interest includes political economy and media regulations, media and democratization, as well as journalism. Email: puji.rianto@uii.ac.id 


\section{REFERENCES}

Aubin, F. (2014). Between public space(s) and public sphere(s): An assessment of Francophone contributions. Canadian Journal of Communication, 39, 89-110.

Carmona, M. (2015). Re-theorising contemporary public space: A new narrative and a new normative. Journal of Urbanism, 8(4), 373-405.

Crawford, M. (1995). Contesting the public realm: Struggles over public space in Los Angeles. Journal of Architectural Education, 49(1), 4-9.

Creswell, J. W. (2015). Penelitian kualitatif \& desain riset: Memilih diantara lima pendekatan (Trans. A. L. Luzuardi). Yogyakarta: Pustaka Pelajar.

Esfandfard, E., Wahab, M. H., \& Amat, R. C. (2018). Universal design in urban public spaces for people with disability: Case study of Tehran, Iran. Journal of the Malaysian Institute of Planners, 16(1), 173-182.

Gaffikin, F., Mcdowney, M., \& Sterrett, K. (2010). Creating shared public space in the contested city: The role of urban design. Journal of Urban Design, 15(4), 493-513.

Gehl, J., \& Matan, A. (2009). Two perspectives on public spaces. Building Research \& Information, 37(1), 106-109.

Hardiman, F. B. (2010). Komersialisasi ruang publik menurut Hannah Arendt dan Jürgen Habermas. In F. B. Hardiman (Ed.), Ruang publik: Melacak "partisipasi demokratis" dari polis sampai cyberspace. Yogyakarta: Kanisius.

Harsanto, P. W. (2014). Yogyakarta dalam kepungan iklan (sebuah kajian tentang estetika lingkungan). Jurnal Dekade, 7(2), 45-55.

Harvey, D. (2009). Neoliberalisme dan restorasi kelas kapitalis (Trans. E. Prasetyo). Yogyakarta: Resist.

Haryatmoko. (2016). Membongkar rezim kepastian: Pemikiran kritis post-strukturalis. Yogyakarta: Kanisius.

Herry-Priyono, B. (2004). Marginalisasi à la neoliberal. Basis, No. 05-06, Year 53.

Herry-Priyono, B. (2010). Menyelamatkan ruang publik. In F. B. Hardiman (Ed.), Ruang publik: Melacak "partisipasi demokratis" dari polis sampai cyberspace. Yogyakarta: Kanisius.

Imam, H. M. (2010). "Masyarakat warga" dalam pemikiran Antonio Gramsci. In F. B. Hardiman (Ed.), Ruang publik: Melacak "partisipasi demokratis" dari polis sampai cyberspace. Yogyakarta: Kanisius.

Ismail, W. A. W., \& Said, I. (2014). Integrating the community in urban design and planning of public spaces: A review in Malaysian cities. Asia Pacific International Conference on Environment-Behaviour Studies, Berlin, 24-26 February.

Phillips, L., \& Jorgensen, M. (2007). Analisis wacana: Teori dan metode (Trans. I. Suyitno et al.). Yogyakarta: Pustaka Pelajar.

Mateo-Babiano, I. B. (2012). Public life in Bangkok's urban spaces. Habitat International, 36, 452-461.

Nasution, A. D., Shalleh, A. G., \& Wahid, J. (2014). Liveable public open space for citizen's quality of life in Medan, Indonesia. International Transaction Journal of Engineering, Management, Applied Sciences \& Technologies, 131-142.

Nasution, A. D., \& Zahrah, W. (2016). Public open space as urban architecture: Design and public life. 8th International Conference on Architecture Research and Design (AR+DC). November 1-2.

Németh, J. (2012). Controlling the commons: How public is public space?. Urban Affairs Review, $\mathrm{XX}(\mathrm{X}), 1-25$. 
The Loss of Public Sphere: Outdoor Advertising and Commercialization of Public Spaces in Sleman, Yogyakarta, Indonesia

Puji Rianto

Parkinson, J. R. (2012). Democracy and public space: The physical sites of democratic performance. Oxford: Oxford University Press.

Parkinson, J. R. (2013). How is space public? Implications for spatial policy and democracy. Environment and Planning C: Government and Policy, 31, 682-699.

Peraturan Pemerintah Republik Indonesia Nomor 26 Tahun 2008 Tentang Rencana Tata Ruang Wilayah Nasional.

Peraturan Bupati Sleman Nomor 53 Tahun 2015 Tentang Penyelenggaraan Reklame.

Peraturan Bupati Sleman No 13.1/2018 Tentang Penyelenggaraan Reklame.

Purbadi, Y. D. (2012). Privatisasi ruang publik di koridor Jalan Tambakbayan Kawasan Babarsari Yogyakarta. Indonesia: Universitas Mercubuana.

Ratnasari, Y. (2016, August 4). Iklan luar ruang masih lebih efektif untuk promosi. Tirto.id.

Sastrapratedja, M. (2010). Ruang publik dan ruang privat dalam tinjauan kebudayaan. In F. B. Hardiman (Ed.), Ruang publik: Melacak "partisipasi demokratis" dari polis sampai cyberspace. Yogyakarta: Kanisius.

Setiawan, D., Haryono, T., \& Burhan, A. (2014). The public space of "Jogja Fashion Week Carnival" and cosplay clothing in Yogyakarta. Jurnal Komunitas, 6(2), 89-196.

Stake, R. A. (2009). Studi kasus. In N. K. Denzin \& Y. S. Lincoln (Eds.), Handbook of qualitative research (Trans. Dariyatno et al.). Yogyakarta: Pustaka Pelajar.

Usada, F. (2015). "Jogja Ora Didol" representasi perlawanan masyarakat Yogyakarta: Studi Kasus Grup Musik Jogja Hip Hop Foundation (Thesis, Jurusan Etnomusikologi, ISI Yogyakarta).

Voronkova, L., \& Pachenkov, O. (2012). Open/closed public spaces in modern cities. Berkeley Planning Journal, 24, 197-206.

Wicaksono, E., Susilo, M. E., \& Lestari, P. (2008). Iklan luar ruang: Antara kepentingan ekonomi dengan kepentingan publik. Jurnal IImu Komunikasi, 6(2), 131-144.

Yin, R. K. (2006). Studi kasus: Desain dan metode (Trans. M. D. Mudzakir). Jakarta: Rajawali Pers. 